\title{
Limited Usefulness of In Vitro Toxicity Data in Hazard Identification of Nanomaterials
}

\author{
David Y Lai* \\ US Environmental Protection Agency, Office of Chemical Safety and Pollution Prevention, USA
}

Submission: May 15, 2017; Published: June 05, 2017

*Corresponding author: David Y Lai (retired), US Environmental Protection Agency, Office of Chemical Safety and Pollution Prevention, Washington DC, USA, Tel: 703-980-2850; Email: dylai09@gmail.com

\begin{abstract}
Short-term in vitro tests of toxicity can provide a rapid and relatively inexpensive way to assess the potential toxicity of large numbers of untested nanoparticles, and therefore, the number of in vitro studies of nanomaterials in the literature has sky rocketed in recent years. However, there are a number of inherent issues of in vitro test systems that result in false positives and false negatives, and recent studies have shown little correlation between in vitro and in vivo toxicity of nanomaterials. Some generic and specific issues of in vitro toxicity testing of nanomaterials are discussed.
\end{abstract}

Keywords: In vitro tests; Toxicity studies; Nanomaterials; Nanoparticles

Abbreviations: LDH: Lactose Dehydrogenase; TGF-B: Transforming Growth Factor-B; MTT: Mitochondrial Reduction of Tetrazolium

\section{Introduction}

With the increasing use and development of engineered nanomaterials in electronics, pesticides, consumer products, and chemical and pharmaceutical industries, there is a growing concern about their potential risks to humans and the environment. The toxic effects of most nanomaterials have not been characterized, but it is generally believed that nanoparticles can have toxicological properties that differ from their bulk materials. A challenge facing hazard identification and safety assessment of engineered nanomaterials is the diversity and complexity of the types of materials with varying physicochemical properties, many of which can affect their toxicity by different mechanisms [1].

Inhalation is the "gold standard" in regard to method of exposure of the respiratory tract for hazard identification of fibers and particles and to obtain dose-response data in quantitative risk assessment since inhalation is the normal physiological route for delivery of particles in the lungs. However, inhalation studies are costly, use large number of animals, take long time to complete, and require sophisticated exposure facilities. As a result, very few in vivo studies are available for engineered nanomaterials. On the other hand, short-term in vitro tests of toxicity can provide a rapid and relatively inexpensive way to assess the potential toxicity of large numbers of untested nanoparticles. Hence, the number of in vitro studies of nanomaterials in the literature has sky rocketed in recent years.

\section{Issues of In Vitro Systems}

A review of the toxicity studies of fibers by an expert panel has concluded that no single short-term in vitro test (or battery of tests)can be used to predict the carcinogenicity potential of fibrous particles [2]. At present, in vitro test systems also appear to have limited usefulness for hazard identification of nanoparticles due to a number of inherent issues resulting in false positives and false negatives. Some generic issues associated with the in vitro approach include:

(i) High-dose effects - effects observed at high-dose levels used in in vitro as says may not extrapolate to low-dose effects in vivo.

(ii) Time course effects - short-term in vitro endpoints (e.g. release of inflammatory mediates. cell proliferation) may not be predictive of long-term physiological effects.

(iii) Cell line effects - toxic responses may differ using different cell lines.

In addition, there are a number of issues specific to in vitro toxicity testing of nanoparticles:

(i) A number of end points employ the measurement of a cellular product, such as release of a protein. Recent data from several research groups [3-5] have demonstrated that various types of nanoparticles can absorb key proteins 
such as albumin, LDH, fibronectin, and T GF- $\beta$, leading to confounding end point measurements.

(ii) Some nanomaterials such as carbon nanotubes have been shown to interfere with the MTT cytotoxicity assay by absorbing the reduced formazandye, resulting in an underestimation of cytotoxic potency [6].

(iii) Many assays employ the measurement of a colored or fluorescent product. For instance, fluorescent nanoparticles such as quantum dots may interfere with the product used to quantity specific cellular responses [7].

(iv) Under in vitro cell culture conditions ('wet phase'), physicochemical characterization of particles including particle size are likely to change from the powder form ('dry phase'). The type and composition of culture medium (e.g. addition of serum) can affect toxicity measurements - probably due to influences affecting agglomeration and/or surface chemistry of nanoparticle [8].

(v) Use of organic solvents for creating suspensions or dispersive agents/surfactants to maintain the nanoparticles from forming aggregates may not be relevant to normal exposure conditions, and these agents may have biological activity that can confound the findings. Incomplete removal of the organic solvent tetrahydrofuran used to create water-soluble suspensions of $\mathrm{C}_{60}$ is believed to contribute to the cytotoxicity of $\mathrm{C}_{60}$ in human cells [9].

(vi) The particokinetics of nanomaterials in culture media is often not considered, resulting in erroneous dose-responses [10].

(vii) New mechanisms may be missed leading to false negatives. For instance, while inflammation and oxidative stress have been identified as possible mechanisms underlying the etiology of nanoparticles, the toxicity of cationic dendrimers appears to be related not to oxidative stress generation, but to disruption of cell membrane integrity through interaction of the positive charge terminal group with the anionic lipids of the cell membrane [11].

Therefore, depending on the type of cells, the duration of exposure, the concentration of nanoparticles and the composition of the culture media, testing of the same nanomaterial can have different outcomes. Recent studies have shown little correlations between in vitro and in vivo toxicity of some nanomaterials. For instance, Sayes et al. [12] assessed the capacity of in vitro screening studies to predict in vivo pulmonary toxicity of several fine or nano-sized particles in rats, including carbonyl iron, crystalline and amorphous silica and zinc oxide. For the in vitro component of the study, different culture conditions were utilized. In the in vivo component of the study, rats were exposed by intratracheal instillation to each of the materials. Following exposures, the lungs of exposed rats were lavaged and end points were measured at numerous time points postexposure. When considering the range of toxicity endpoints, the comparisons of in vivo and in vitro measurements demonstrated little correlation. Similarly, whereas nano-C60 and $\mathrm{C}_{60}(\mathrm{OH})_{24}$ were reported to be toxic to a number of cell types in vitro [13], there was no evidence of adverse effects in lung tissues at three months post-instillation exposure to doses up to $3 \mathrm{mg} / \mathrm{kg}$ of the two types of fullerenes in rats [14]. In vitro assays of oxidant stress also failed to predict the progressive interstitial fibrotic response to inhalation exposure to single-walled carbon notubes (SWCNTs) [15,16].

Low-throughput in vitro testing methods for nanomaterials have improved in recent years. For instance, interaction with colorimetric indicator dyes confounding the measurement when testing the toxicity of carbon nanomaterials could be avoided by employing the clonogenic assay which does not use any dye or stain [17]. A nanoparticle dispersion system using an electrospray method to deliver nanoparticles for in vitro nanotoxicity studies has been developed [18]. Nonetheless, the poor correlations between in vitro and in vivo toxicity data of nanomaterials can also be due to the toxicokinetic of nanoparticles in animals. All nanoparticles, upon exposure to tissues and fluids of the body, will immediately adsorb on to the surface of some of the macro molecules that they encounter. The specific features of this adsorption process will depend upon the size and surface characteristics of the particles, including surface chemistry and surface energy [19]. One paradigm of nanoparticle toxicity is the ability of some nanoparticles to form acorona with proteins, which leads to adverse biological effects through protein unfolding, fibrillation, thiol cross-linking and loss of enzyme activity [20].

It has also been found that for certain nanoparticles the clearance mechanism may be less effective than for larger particles after deposition in the respiratory tract. Their small size helps them to enter the cells by endocytosis and reach the circulating system, eventually reaching various potential target sites [21,22]. Dissolution appears to be one of the key elements for determining the biological fate and effects of some nanoscale materials [23]. Other nanoparticle characteristics and agglomeration/aggregation state can also affect their deposition, distribution, metabolism and excretion [1].

\section{Conclusion}

Due to the issues of in vitro systems and the toxicokinetics issues discussed above, many of the in vitro toxicity data reported in the literature are of limited value in hazard identification of nanomaterials. For the same reasons, screening strategies [24-26] developed for the hazard identification process of nanomaterial risk assessment which start with using short-term in vitro screening assays, are prone to fail and unlikely to be validated later by animal studies. Adequate in vivo toxicity studies on nanomaterials are scarce [27]. Therefore, the scientific community has not been able to definitely determine which nanomaterials and which are not, hazardous to humans or the environment. Conflicting results are often reported for 
nanomaterials of the same class/subclass or seemingly identical materials. The challenges in toxicity testing and risk assessment of nanomaterials have been discussed.

Testing every nanomaterial in animals is impractical, if not impossible. As toxicity testing of nanoparticles by the traditional approach appears problematic, a paradigm setting a stage for "toxicity testing of nanomaterials in the 21st century" has been proposed [28]. In this paradigm, only a small number of short-term in vivo studies in rodents are necessary to first characterize the toxicological properties of reference materials of each class/subclass of nanoparticles. In vivo and in vitro high-throughput genomics and/or proteomics studies are then performed to investigate the underlying molecular mechanisms/ toxicity pathways and biomarkers of the toxic responses. As in vitro studies allow specific biological and mechanistic pathways to be isolated and test edunder controlled conditions, mechanism-based short-term in vitro assays in appropriate cell lines (preferably of human origin and at target tissues) may be conducted to aid in elucidation or interpretation of mechanisms, toxicity pathways and biomarkers data derived from the in vivo animal studies. Once these mechanistic data on reference materials are obtained, they can be used to bench mark the effects and the hazard potential of any nanoparticle belonging to the same class/subclass by comparing data of their highthroughput in vitro and/or mechanism-based short-term in vitro assays. In other words, animal studies are no long needed and hazard potential of any nanomaterial can be semi-qualitatively evaluated by toxicity testing under this paradigm [28].

\section{Reference}

1. Lai DY, Sayre PG (2009) Toxicity testing and evaluation of nanoparticles: Challenges in risk assessment. In: Sahu SC, Casiano DA (Eds.), Nanotoxicity: From In Vivo to In Vitro Models to Human Risks. Wiley \& Sons, USA, pp. 427-457.

2. Bernstein D, Castranova V, Donaldson K, Fubini B, Hesterberg T, et al. (2005) Testing of fibrous particles: Short-term assays and strategies. Inhal Toxicol 17(10): 497-531.

3. Brown DM, Stone V, Findlay P, MacNee W, Donaldson K (2000) Increased inflammation and intracellular calcium caused by ultrafine carbon black is independent of transition metals or other soluble components. Occup Environ Med 57(10): 685-691.

4. Kim H, Liu X, Kobayashi T, Kohyama T, Wen FQ et al .(2003)Ultrafine carbon black particles inhibit human lung fibroblast-mediated collagen gel contraction. Am J Respir Cell Mol Biol 28(1): 111-121.

5. DuttaD, Sunddaram SK, Teeguarden JG, Riley BJ, Fifiels LS, et al. (2007) Adsorbed proteins influence the biological activity and molecular targeting of nanomaterials. Toxiocol Sci 100(1): 303-315.

6. Worle-Knirsh JM, Pulskam PK, Krug HF (2006) Oops they did it again! Carbon nanotubes hoax scientists inviability assays. Nano Lett 6(6): 1261-1268.

7. Monteiro-Riviere NA, Inman AO (2006) Challenges for assessing carbon nanomaterial toxicity to the skin. Carbon 44(6): 1070-1078.

8. Murdock RC, Braydich-Stolle L, Schlager AM, Hussain SM (2008) Characterization of nanomaterial dispersion in solution prior to in vitro exposure using dynamic lights scattering technique. Toxicol Sci 101(2): 239-253.
9. AndrievskyG, Klochkov V, Derevyanchenko L (2005) Is the C60 fullerene molecule Toxic? Fuller Nanotubes and Carbon Nano structures 13(4): 363-376.

10. Teeguarden JG, Hinderliter PM, Orr G, Thrall BD, PoundsJG (2007) Particokinetics In Vitro: Dosimetry Considerations for In Vitro Nanoparticle Toxicity Assessments. Toxicol Sci 95(2): 300-312.

11. Mecke A, Orr BG, Banaszak Holl MM, Baker JR (2005) Lipid bilayer disruption bypoly amido amine dendrimers: the role of generation and capping group. Langmuir 21: 10348-10354.

12. Sayes CM, Reed KL, Warheit DB (2007) Assessing toxicity of fine and nanoparticles: comparing in vitro measurements to in vivo pulmonary toxicity profiles. Toxicol Sci 97(1): 163-180.

13. Sayes C, Fortner J, Guo W, Lyon D, Boyd A, et al. (2004) The differential cyto toxicity of water-soluble fullerenes. Amer Chem Soc 4(10): 18811887.

14. Sayes CM, Marchione AA, Reed KL, Warheit DB (2007) Comparative pulmonary toxicity assess- ment of $\mathrm{C} 60$ water suspensions in rats: few differences in fullerene toxicity in vivo in contrast to in vitro profiles. Nano Lett 7(8): 2399-2406.

15. Shvedova AA, Kisin ER, Murray AR, Johnson VJ, Gorelik 0, et al. (2008) Inhalation vs. aspiration of single-walled carbon nanotubes in C57BL/6mice:inflammation, fibrosis, oxidative stress, and mutagenesis. Am JPhysio lLung Cell Mol Physiol 295(4): L552-L565.

16. Kagan VE, Tyurina YY, Tyurin VA, Kondura NV, Potapovich AI, et al. (2006) Direct and indirect effect of single walled carbon nanotubes on RAW 264.7 macrophages: Roleofiron. Toxicol Lett 165(1): 88-100.

17. Herzog E, Casey A, Lyng FM, Chambers G, Byrne HJ, et al. (2007) A new approach to the toxicity testing of carbon-based nanomaterials - the clonogenic assay. Toxicol Lett 174(1-3): 49-60.

18. Kim SC, Chen DR, Qi CL, Gelein RM, Finkelstein JN, et al. (2010) A nanoparticle dispersion method for in vitro and in vivo nanotoxicity study. Nanotoxicology 4(1): 42-51.

19. SousaSR, Ferreira PM, Saramago B, MeloLV, Barbosa MA (2004) Human serum adsorptionon $\mathrm{TiO} 2$ from single protein solutions and fromplasma. Langmuir 20(22): 9745-9754.

20. Cedervall T, Lynch I, Lindman S, Berggard T, Thukin E, et al. (2007) Understanding the nanoparticle-protein corona using methods to quantify exchange rate sand affinity to proteins for nano particles. Proc Natl Acad Sci 104(7): 2050-2055.

21. Limbach LK, Li Y, Grass RN, Brunner TI, Hintermann MA, et al. (2005) Oxide nano particle uptake in human lung fibroblasts: effects of particle size, agglomeration, and diffusion at low concentration. Environ Sci Technol 39(23): 9370-9376.

22. Oberdörster G, Oberdörster E, Oberdörster J (2005) Nanotoxicology: An emerging discipline evolving from studies of ultrafine particle. Environ Health Perspect 113(7): 823-839.

23. Borm P, Klaessig FC, Landry TD, Moudgil B, Pauluhn J, et al. (2006) Research strategies for safety evaluation of nanomaterials, PartV: Role of dissolution in biological fate and effects of nanoscale particles. Toxicol Sci 90(1): 23-32.

24. Oberdörster G, Maynard A, Donaldson K, Castranova V, Fitzpatrick JW, et al. (2005) Principles for characterizing the potential human health effects from exposure to nanomaterials: Elements of a screenings trategy. Particle Fibre Toxicol 2: 8.

25. Nel A, Xia T, Men H, Wang X, Lin S, et al. (2012) Nanomaterial Toxicity Testing in the $21^{\text {st }}$ Century: Use of a Predictive Toxicological Approach and High Throughput Screening. Acc Chem Res 46(3): 607-621.

26. Clippinger AJ, Ahluwalia A, Allen D, Bonner JC, Casey W, et al. (2016) Expert consensus on an in vitro approach to assess pulmonary 
fibrogenic potential of aerosolized nanomaterials. Arch Toxicol 90(7): 1769-1783.

27. Lai DY, Warheit DB (2015) Nanotoxicology: The case for in vivo studies. Handbook of Safety Assessment of Nanomaterials: From Toxicological Testing to Personalized Medicne. In: Fadeel B (Ed.), Chapter 6, pp. 153219
28. Lai DY (2012) Toward Toxicity Testing of Nanomaterials in the $21^{\text {st }}$ Century: A Paradigm for Moving Forward. WIREs Nanomed Nanobiotechnol 4(1): 1-15.

\section{Your next submission with Juniper Publishers} will reach you the below assets

- Quality Editorial service

- Swift Peer Review

- Reprints availability

- E-prints Service

- Manuscript Podcast for convenient understanding

- Global attainment for your research

- Manuscript accessibility in different formats (Pdf, E-pub, Full Text, Audio)

- Unceasing customer service

Track the below URL for one-step submission https://juniperpublishers.com/online-submission.php 